\title{
A GEOPOÉTICA DE RACHEL DE QUEIROZ
}

\author{
Beatriz Santos de Souza ${ }^{1}$ \\ Universidade Federal do Ceará, Fortaleza, Brasil
}

Sei da importância em ler obras acadêmicas, entretanto durante minhas leituras sinto falta de certa leveza literária que a Geografia, como ciência multidisciplinar, deveria ser capaz de proporcionar. E foi no livro Geografia Literária em Rachel de Queiroz, escrito por Tiago Vieira Cavalcante, que pude finalmente encontrar essa tal leveza que tanto busquei.

Sempre soube que Rachel de Queiroz foi uma escritora capaz de expor um Ceará literário, porém carregado com uma dose ideal da realidade, ligado ao mundo feminino do qual Rachel faz parte. Mas foi a partir da leitura do livro que pude apreender a geograficidade existente nas palavras de Rachel.

A partir da capa o leitor já sente aquela vontade súbita de ler a obra sem a menor intenção de parar. Devo enfatizar que a linda arte de Luci Sacoleira compõe todo o livro e, unida às belas palavras postas pelo autor no decorrer dos capítulos, tornam o momento da leitura algo singular.

Antes de iniciar a leitura propriamente dita, pude desvelar em um caminho introdutório que me levou desde a Geografia Humanista até a Geografia Literária para enfim chegar à Geografia Literária de Rachel de Queiroz. As diferentes abordagens da geografia literária tornaram o livro diversificado.

De maneira simples, mas com um cuidado visível em cada página, pude aprender sobre a Geografia Pessoal de Rachel e toda a construção de sua identidade e pertencimento nos diferentes lugares os quais ela viveu e passou, sendo Quixadá o lugar em que ela fincou as suas raízes e pode finalmente sentir-se pertencente a um lugar.

O escritor é um ser sensível; concordo com Cavalcante sobre o mundo particular e suas vivências serem alimentos de um escritor. Ele possui o que chamamos de "olhar geográfico". É esse olhar que compõe a geografia telúrica de Rachel, além de sua poética e toda uma geograficidade que ela carrega em suas obras.

\footnotetext{
${ }^{1}$ Universidade Federal do Ceará, Graduanda em Geografia - UFC, Bolsista do Programa de Educação Tutorial - PET-UFC, E-mail: beatrizsantosb90@gmail.com
} 
Ao tratar sobre o Caderno de "Geographia" de Rachel, o autor trouxe parte do cotidiano vivido pela escritora, assim como a geografia ensinada na época em que a escritora era uma jovem estudante, o que me encantou, pois são esses registros tão pessoais que dão a possibilidade de conhecer não só uma Rachel antes de ser escritora, mas também todo o contexto escolar no qual a escritora viveu.

Ver o amor que Rachel sentia pelo Ceará quando o autor tratou sobre a obra $O$ Nosso Ceará, em que a escritora apresenta um Ceará belo, mas sem deixar de lado os pontos críticos do estado. Rachel apresenta o seu Ceará que também é nosso. Além disso, desfrutei de uma geografia dos sabores apresentada a partir da análise da obra $O$ Não Me Deixes: Suas Histórias e Sua Cozinha. Fiquei encantada em saber que os sabores podem compor uma geografia peculiar.

O autor também traz em seu livro um capítulo dedicado aos romances publicados por Rachel - O Quinze, João Miguel, Caminho de Pedras, As Três Marias, Dôra, Doralina, O Galo de Ouro a o Memorial de Maria Moura, em que de forma poética e geográfica foi capaz de captar a espacialidade e geograficidade que Rachel depositou em seus romances. Entre todos eles, a análise do Memorial de Maria Moura ganhou parte do meu afeto, pois é nele que Rachel retrata um sertão forte feminino.

No decorrer do livro, em meio a citações de Rachel, pareceu que sempre estive em uma varanda, no embalo de uma rede, com um vento refrescante saudado pelo doce cantar de pássaros, com a própria Rachel ao meu lado contanto sua história e sua geografia, acompanhada de um bom bolo e um café quentinho. É essa sensação, de pertencer e viver a obra que torna a leitura única.

A leitura do livro, vale dizer, fez parte do meu cotidiano. Durante minhas idas e vindas à Universidade Federal do Ceará - UFC, dentro de ônibus quase sempre lotados, viajei pelo Ceará folheando página por página. Participei, assim, da geografia itinerante de Rachel, possível apenas pelo poder da imaginação.

A escrita simples torna o livro acessível para todos os gostos, certamente um os objetivos do autor, comprovando que não é necessária uma escrita rebuscada e difícil para se alcançar a excelência. Talvez Rachel, se estivesse viva, ficaria feliz de ler uma obra tão encantadora que de maneira complexa e ao mesmo tempo delicada, foi capaz de captar a essência e existência de sua geografia.

\section{REFERÊNCIAS}


CAVALCANTE, Tiago Vieira. Geografia Literária em Rachel de Queiroz. Fortaleza: Edições UFC, 2019.

Recebido em 26/08/2019.

Aceito em 31/07/2017.

Publicado em 15/10/2020. 